\title{
Comparison of Terbutryn Acute Toxicity to Danio rerio and Poecilia reticulata
}

\section{Lucie Plhalová, Stanislava Mácová, Petra Doleželová, Petr Maršálek, Zdeňka Svobodová,} Vladimíra Pištěková, Iveta Bedáňová, Eva Voslářová, Helena Modrá

Department of Veterinary Public Health and Toxicology, Faculty of Veterinary Hygiene and Ecology, University of Veterinary and Pharmaceutical Sciences Brno, Czech Republic

Received February 16, 2010

Accepted June 15, 2010

\begin{abstract}
The aim of the present study was to determine and compare acute toxicity of terbutryn in Danio rerio and Poecilia reticulata, and in two different developmental stages of $D$. rerio - embryonic and juvenile. Acute toxicity tests were performed according to OECD methodology. The LC50 values were assessed by probit analysis using EKO-TOX 5.2 programme. The 96hLC50 terbutryn mean value of 5 tests was $2.85 \pm 0.75 \mathrm{mg} \cdot \mathrm{l}^{-1}$ for the juvenile stage of $P$. reticulata and $5.71 \pm$ $0.46 \mathrm{mg} \cdot 1^{-1}$ for the juvenile stage of $D$. rerio. For the embryonic stage of $D$. rerio the $144 \mathrm{hLC} 50$ terbutryn mean value of 6 tests was estimated as $8.04 \pm 1.05 \mathrm{mg} \cdot \mathrm{l}^{-1}$. The study proved significantly higher $(p<0.01)$ sensitivity of the juvenile stage of $D$. rerio to terbutryn compared to the embryonic stage of $D$. rerio and significantly higher $(p<0.01)$ sensitivity of the juvenile stage of $P$. reticulata to terbutryn compared to the juvenile stage of $D$. rerio. herbicides. This study documented differences in sensitivity of several fish species and different developmental stages of fish to one of triazine.
\end{abstract}

Embryonic stage, juvenile stage, zebrafish, guppy, LC50

Terbutryn (2-(tert-butylamino)-4-(ethylamino)-6-(methylthio)-s-triazine) belongs to substituted symmetrical triazines. Triazines form a group of similar herbicides used extensively in agriculture and non-agricultural sites, primarily to control broadleaf and some grassy weeds that have become ubiquitous contaminants of the environment (Muir 1980; Moretti et al. 2002; Arufe et al. 2004). Triazine herbicides are divided into two groups, asymmetrical triazines or triazinones, such as metribuzin, and symmetrical triazines. The most commercially used symmetrical triazines are simazine, atrazine, propazine, cyanazine, ametryn, prometryn, prometon and terbutryn (Stevens et al. 2001). Herbicidal activity of triazines was first discovered in 1952 by J. R. Geigy in Switzerland (Roberts et al. 1998).

Terbutryn has been used worldwide for the control of most annual grasses and broadleaf weeds in many crops including winter cereals, potatoes, legumes, maize, sugarcane and citrus. Terbutryn is a selective systemic herbicide which acts as a photosynthesis inhibitor in the xylem and accumulates in the apical meristems. In plants it is metabolised by oxidation to 2-hydroxy derivates and by side-chain de-alkylation. Terbutryn is also used in the aquatic environment as an aquatic herbicide for the control of algae, submerged and free-floating weeds and may affect many non-target organisms there (Muir 1980; Roberts et al. 1998; Arufe et al. 2004). The application of terbutryn has been banned in many countries because of its the potential to bioaccumulate in organisms, but it can be still detected in the water environment (Rioboo et al. 2007). The preparations containing terbutryn have not been registered in the Czech Republic since 2005, however, terbutryn can be still detected in the environment. Its highest environmental concentration was found in the Czech rivers and according to the Czech Hydrometeorological Institute report it was $0.02 \mu \mathrm{g} \cdot \mathrm{l}^{-1}$ in 2008 .

The acute toxicity of chemical substances depends on many factors, such as species, Address for correspondence:

Mgr. Lucie Plhalová

Department of Veterinary Public Health and Toxicology

Faculty of Veterinary Hygiene and Ecology

University of Veterinary and Pharmaceutical Sciences Brno

Palackého 1-3, 61242 Brno, Czech Republic

Phone: +420 541562781

Fax: +42054156 2790

E-mail: lplhalova@vfu.cz

http://www.vfu.cz/acta-vet/actavet.htm 
age, body weight, feeding conditions, intermediary metabolism rate, temperature, salinity, concentration of oxygen dissolved in the water, etc. (Mayer, Jr. and Ellersieck 1988). Median lethal concentration (LC50) values of organic chemicals in different fish species can often differ by factors of 10 or more and toxicity testing with only one fish species may be inadequate to classify chemicals belonging to these classes for their environmental impact (Geyer et al. 1993; Gallo et al. 1995). Danio rerio and Poecilia reticulata belong among fish species recommended by OECD Guidelines for Testing of Chemicals and to species frequently used in aquatic toxicology (Svobodová and Vykusová 1991; Gallo et al. 1995; Kovrižnych and Urbančíková 2001; Hill et al. 2005; Jurčíková et al. 2007; Voslářová et al. 2008; Mikula et al. 2009; Plhalová et al. 2009).

The aim of the present study was to determine and to compare the mean lethal concentration of terbutryn in embryonic and juvenile developmental stages of $D$. rerio and juvenile developmental stages of $P$. reticulata.

\section{Materials and Methods}

Experimental fish

Tests of terbutryn toxicity were performed on the aquarium fishes $D$. rerio and $P$. reticulata. Experimental procedures were in compliance with the national legislation (Act No. 246/1992 Coll., on the protection of animals against cruelty, as amended and decree No. 207/2004 Coll., on the protection, breeding and use of experimental animals). All fish were held for a minimum of 7 days in the aquaria for the acclimatization period during which they were fed with commercial fish pellets. Food was withheld $24 \mathrm{~h}$ preceding start of the test.

Acute toxicity test

The acute toxicity tests on juvenile stage of $D$. rerio and $P$. reticulata were performed according to the method OECD No. 203 Fish, Acute Toxicity Test in the series of five tests. We dissolved terbutryn by the addition of dimethyl sulphoxide (DMSO) as terbutryn exhibits low water solubility. This stock solution was applied to particular test vessels, the highest DMSO concentration in test vessels being $0.1 \%$. In each test series we used five ascending concentrations of the tested substance $\left(0.5 ; 2.0 ; 3.5 ; 5.0 ; 7.5 \mathrm{mg} \cdot 1^{-1}\right)$ for P. reticulata and $(4.0 ; 5.0$; $6.0 ; 7.0 ; 8.0 \mathrm{mg} \cdot \mathrm{l}^{-1}$ ) for D. rerio and two control groups (one control group in the dilution water only and another control group in the dilution water with the solvent - DMSO in the amount of $0.1 \%$ ). Ten juvenile fish (aged 2-3 months, randomly selected from the stock population) were placed in each test vessels. We used semi-static test procedure (test solutions were replaced at 24-h intervals). During the tests, the condition of fish was checked and the number of dead fish was recorded for different concentrations every $24 \mathrm{~h}$ as well as the water temperature, $\mathrm{pH}$ and the oxygen saturation of water. Water temperature in the tests ranged $23 \pm 2{ }^{\circ} \mathrm{C}$. Dissolved oxygen concentrations were above $60 \%(62.5-89.9 \%)$, the $\mathrm{pH}$ was between 7.87 and 8.36 . No fish from control groups died during any of the tests. The duration of these tests was $96 \mathrm{~h}$ for each of them.

Embryonic toxicity test

Toxicity tests in the embryonic stage of D. rerio were performed according to the method OECD No. 212 Fish, Short-term Toxicity Test on Embryo and Sac-Fry Stages in the series of six tests. In each test series we used five ascending concentrations of the tested substance $\left(7.5 ; 10 ; 12.5 ; 15 ; 17.5 \mathrm{mg} \cdot \mathrm{l}^{-1}\right.$ ) and two controls (one control in the dilution water only and the other one in the dilution water and solvent - DMSO at the amount of $0.1 \%$ ). Twenty fertilized eggs were placed in Petri dishes. The eggs were placed in Petri dishes within $8 \mathrm{~h}$ at the latest after the fertilization. The tests were terminated after hatching and the absorption of the yolk sack in the control dish (144 $\mathrm{h}$ after initiation). We used the semi-static test procedure, the solutions were replaced at 24-h intervals. During the tests, numbers of dead embryos at individual concentrations were recorded. The mortality rate of the control embryos did not exceed $20 \%$. Water temperature in the tests ranged $25 \pm 1{ }^{\circ} \mathrm{C}$.

The results and statistical analysis

The results of acute toxicity tests (the number of dead fish in individual test concentrations) on embryonic and juvenile stages were processed by the probit analysis (EKO-TOX 5.2 programme) to determine the LC50 terbutryn values (for embryonic stage 144hLC50 and for juvenile stage 96hLC50). The significance of the difference between LC50 values for embryonic and juvenile stages of $D$. rerio and juvenile stage of $P$. reticulata was calculated using the non-parametric Mann-Whitney test and Unistat 5.1 software.

Water quality indicators

The basic physical and chemical properties of the dilution water used in toxicity tests were: $\mathrm{COD}_{\mathrm{Mn}}$ (chemical oxygen demand) $1.4-1.9 \mathrm{mg} \cdot \mathrm{l}^{-1}$; total ammonia below the limit of detection; $\mathrm{NO}_{3}^{-} 24.5-31.4 \mathrm{mg} \cdot 1^{-1}$; $\mathrm{NO}_{2}^{-}$below the limit of determination; $\mathrm{Cl}^{-} 18.9-19.1 \mathrm{mg} \cdot \mathrm{l}^{-1} ; \Sigma \mathrm{Ca} \pm \mathrm{Mg} 14 \mathrm{mg} \cdot \mathrm{l}^{-1}$.

Determination of terbutryn

Gas chromatography with ion trap mass spectrometry (GC/IT-MS) was used for the determination of terbutryn. 
Preparation of the unfiltered sample was based on the simple liquid-liquid extraction into hexan. Separation, identification and quantification of terbutryn were based on the GC/IT-MS method described by Djozan and Ebrahimi (2008). Gas chromatograph Varian 450-GC with Varian 220-MS ion trap mass spectrometer and VF$5 \mathrm{~ms}(30 \mathrm{~m} \times 0.25 \mathrm{~mm})$ column were used for the separation of terbutryn. Detection limit $(3 \sigma)$ of terbutryn was $0.01 \mu \mathrm{g} \cdot \mathrm{l}^{-1}$. Expanded uncertainty was $6.5 \%$ on the condition that coefficient of expansion was $\mathrm{k}=2$. In all toxicity tests, the concentration of terbutryn after $24 \mathrm{~h}$ was above $80 \%$ of the dosed initial concentration.

\section{Results}

The 144 hLC50 terbutryn mean value for embryonic stage of $D$. rerio was estimated as $8.04 \pm 1.05 \mathrm{mg} \cdot \mathrm{l}^{-1}$ (ranging from 6.71 to $8.91 \mathrm{mg} \cdot \mathrm{l}^{-1}$ ). The mean cumulative mortality of $D$. rerio during embryonic toxicity tests is showed in Fig. 1 . For the juvenile stage of $D$. rerio the $96 \mathrm{hLC} 50$ mean value was $5.71 \pm 0.46 \mathrm{mg} \cdot \mathrm{l}^{-1}$ (ranging from 5.20 to $6.13 \mathrm{mg} \cdot \mathrm{l}^{-1}$ ). The mean cumulative mortality of $D$. rerio in particular concentrations of acute toxicity tests is presented in Fig. 2. Results of this study showed significantly higher $(p<0.01)$ sensitivity of juvenile fish to terbutryn compared to the embryonic stages of $D$. rerio.

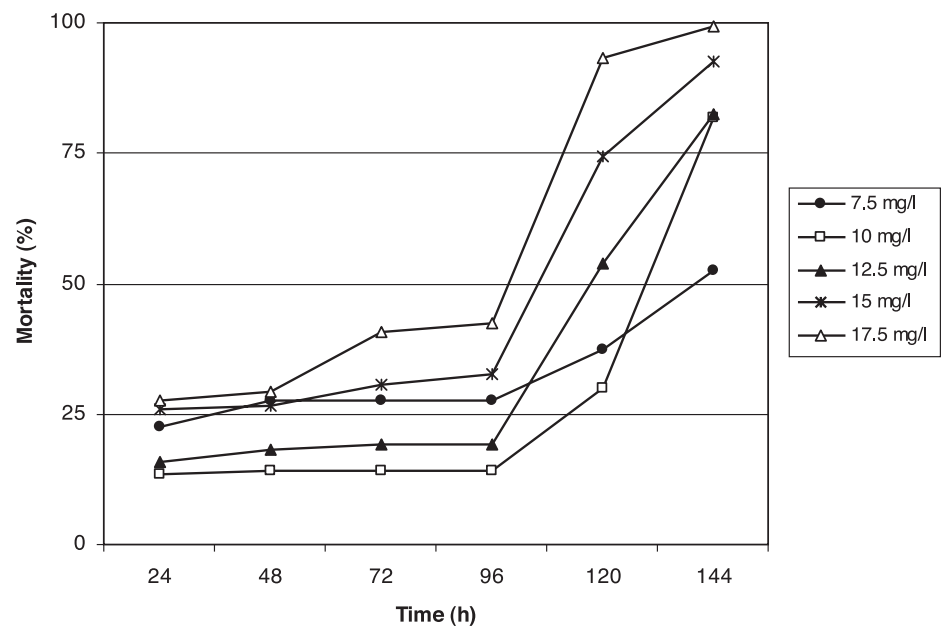

Fig. 1. Mean cumulative mortality of $D$. rerio during embryonic toxicity tests

The 96hLC50 terbutryn mean value for the juvenile stage of Poecilia reticulata was estimated as $2.85 \pm 0.75 \mathrm{mg} \cdot \mathrm{l}^{-1}$ (ranging from 2.07 to $3.93 \mathrm{mg} \cdot \mathrm{l}^{-1}$ ). The mean cumulative mortality of $P$. reticulata at particular concentrations in acute toxicity tests is presented in Fig. 2.

The comparison of terbutryn LC50 mean values for $D$. rerio and $P$. reticulata showed significantly higher $(p<0.01)$ sensitivity of $P$. reticulata compared to $D$. rerio.

\section{Discussion}

This study showed that the juvenile stages of $D$. rerio are more sensitive to terbutryn than the embryonic stages of $D$. rerio. Majority of studies show that sensitivities of the embryonic and juvenile stages of $D$. rerio are comparable, however, in several cases, juvenile fish have been found to be more sensitive depending on the substance tested. Newly hatched larvae constitute a particularly critical and sensitive life stage, because at hatching the embryos lose their protective membrane and are fully exposed to potential toxicants (Arufe et al. 2004). On the other hand, Kovrižnych and Urbančíková (2001) 


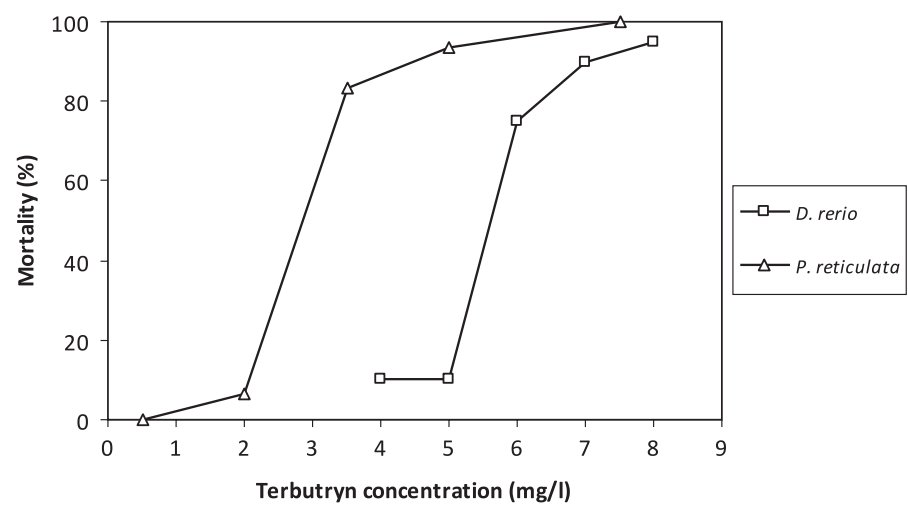

Fig. 2. Mean cumulative mortality of $D$. rerio and $P$. reticulata at particular concentrations in acute toxicity tests

tested eight chemical substances (acetochlor, acrylamide, benzene, colchicine, diethylene glycol, diethylnitrosamine, methanol and Triton X-100) and their toxicity data showed that the results of tested substances were comparable in 7 of 8 chemicals for both life stages of $D$. rerio (adult fish and embryos on eggs). Pištěková et al. (2006) and Mácová et al. (2008) stated very diverse susceptibility to chemical substances. These authors reported that juvenile fish are more sensitive than embryonic stages of $D$. rerio. Pištěková et al. (2006) studied the effect of age of D. rerio on nitrite toxicity. Mácová et al. (2008) found higher sensitivity in juvenile fish of $D$. rerio to 2-phenoxyethanol, but acute toxicity values of clove oil for juvenile and embryonic stages were comparable.

This study proved that $P$. reticulata is more sensitive to terbutryn than $D$. rerio. The results of the present and other studies confirm that acute toxicity depends not only on age but also on the species studied (Table 1). Gallo et al. (1995) tested two carbamates, aldicarb and carbaryl, and found that toxicity of both these carbamates was higher in P. reticulata than in $D$. rerio. Doleželová et al. (2008) observed comparable sensitivity of $D$. rerio and $P$. reticulata to silver nitrate. But $P$. reticulata showed significantly higher $(p<0.05)$ tolerance to sodium chloride than $D$. rerio, whereas $D$. rerio showed significantly higher $(p<0.05)$ tolerance to formaldehyde than $P$. reticulata. The acute toxicity of potassium permanganate was comparable for both fish species (Doleželová et al. 2009). Svobodová and Vykusová (1991) did

Table 1. Comparison of LC50 D. rerio and P. reticulata to different chemical substances

\begin{tabular}{|c|c|c|c|}
\hline \multirow{2}{*}{ Substance } & \multicolumn{2}{|c|}{ LC50 } & \multirow{2}{*}{ Authors } \\
\hline & Danio rerio & Poecilia reticulata & \\
\hline Aldicarb & $52.9 \mu \mathrm{mol} \cdot 1^{-1^{*}}$ & $3.5 \mu \mathrm{mol} \cdot 1^{-1^{*}}$ & \multirow{2}{*}{ Gallo et al. (1995) } \\
\hline Carbaryl & $46.0 \mu \mathrm{mol} \cdot 1^{-1^{*}}$ & $12.5 \mu \mathrm{mol} \cdot 1^{-1^{*}}$ & \\
\hline Silver nitrate & $15.00 \pm 0.52 \mu \mathrm{g} \cdot 1^{-1^{*}}$ & $17.14 \pm 5.43 \mu \mathrm{g} \cdot \cdot^{-1^{*}}$ & Doleželová et al. (2008) \\
\hline Sodium chloride & $10.39 \pm 0.12 \mathrm{~g} \cdot \mathrm{l}^{-1^{*}}$ & $21.69 \pm 0.92 \mathrm{~g} \cdot \mathrm{l}^{-1^{*}}$ & \multirow{3}{*}{ Doleželová et al. (2009) } \\
\hline Formaldehyde & $0.12 \pm 0.003 \mathrm{ml} \cdot 1^{-1^{*}}$ & $0.1 \pm 0.003 \mathrm{ml} \cdot \cdot^{-1^{*}}$ & \\
\hline Potassium permanganate & $1.25 \pm 0.15 \mathrm{mg} \cdot \mathrm{l}^{-1^{*}}$ & $1.43 \pm 0.05 \mathrm{mg} \cdot \mathrm{l}^{-1^{*}}$ & \\
\hline p-nitrofenol & $105.0 \pm 1.48 \mathrm{mg} \cdot \mathrm{l}^{-1^{* *}}$ & $138.4 \pm 8.54 \mathrm{mg} \cdot 1^{-1 * *}$ & \multirow{3}{*}{$\begin{array}{c}\text { Svobodová and Vykusová } \\
\text { (1991) }\end{array}$} \\
\hline Zinc sulfate & $87.6 \pm 15.06 \mathrm{mg} \cdot 1^{-1^{* * *}}$ & $61.0 \pm 4.77 \mathrm{mg} \cdot \mathrm{l}^{-1^{* *}}$ & \\
\hline Potassium dichromate & $25.7 \pm 0.77 \mathrm{mg} \cdot 1^{-1 * *}$ & $25.2 \pm 0.70 \mathrm{mg} \cdot 1^{-1 * *}$ & \\
\hline
\end{tabular}

*96hLC50

**48hLC50 
not find any significant difference between the sensitivity of $D$. rerio and $P$. reticulata to the chemical compound which was commonly used as a standard in toxicity testing - p-nitrofenol. Significantly higher sensitivity to zinc sulphate was recorded in P. reticulata, by contrast $D$. rerio was more sensitive to potassium dichromate than $P$. reticulata.

Bathe et al. (1973), Kidd and James (1991) assessed terbutryn 96hLC50 values for Cyprinus carpio as $4 \mathrm{mg} \cdot \mathrm{l}^{-1}$ and the same LC50 value was found for Lepomis macrochirus. 96hLC50 values for Onchorhynchus mykiss was $3 \mathrm{mg} \cdot \mathrm{l}^{-1}$. Arufe et al. (2004) stated the $72 \mathrm{hLC} 50$ of a commercial herbicide containing terbutryn $(59.4 \%)$ and triasulphuron $(0.6 \%)$ to be $1.41 \mathrm{mg} \cdot 1^{-1}$ for yolk-sack larvae of Sparus aurata, whereas the LC50 values for triasulphuron are well above these values, reported to be $>100 \mathrm{mg} \cdot \mathrm{l}^{-1}$ for the species L. macrochirus and O. mykiss, indicating a significantly lower acute toxicity (Office of Pesticide Programs 2000). The comparison of our LC50 terbutryn values for D. rerio and $P$. reticulata with the LC50 terbutryn values in other fish species showed that the results are practically conformable.

\section{Porovnání akutní toxicity terbutrynu pro Danio rerio a Poecilia reticulata}

Cílem předložené práce bylo stanovit a porovnat akutní toxicitu terbutrynu pro juvenilní stádia Poecilia reticulata a Danio rerio a pro dvě rozdílná vývojová stádia Danio rerio -embryonální a juvenilní. Testy akutní toxicity byly provedeny dle metodiky OECD. Hodnoty LC50 byly stanoveny probitovou analýzou pomocí programu EKO-TOX 5.2. Průměrná hodnota $96 \mathrm{hLC} 50$ terbutrynu pro 5 opakování testů byla $2,85 \pm 0,75 \mathrm{mg} \cdot \mathrm{l}^{-1}$ u juvenilního stádia $P$. reticulata a $5,71 \pm 0,46 \mathrm{mg} \cdot \mathrm{l}^{-1}$ pro juvenilní stádium $D$. rerio. Pro embryonální stádium $D$. rerio byla průměrná hodnota 144 hLC50 terbutrynu pro 6 opakování testů $8,04 \pm 1,05 \mathrm{mg} \cdot \mathrm{l}^{-1}$. Porovnáním hodnot akutní toxicity terbutrynu pro embryonální a juvenilní stádia $D$. rerio byla zjištěna významně vyšší citlivost juvenilního stádia $D$. rerio $(p<0,01)$ a významně vyšší $(p<0,01)$ citlivost juvenilního stádia $P$. reticulata ve srovnání s juvenilním stádiem $D$. rerio.

\section{Acknowledgements}

This research was supported by the Ministry of Education, Youth and Sports of the Czech Republic (MSM Project No. 6215712402 and IGA 200/2009/FVHE).

\section{References}

Arufe MI, Arellano J, Moreno MJ Sarasquete C 2004: Toxicity of commercial herbicide containing terbutryn and triasulfuron to seabream (Sparus aurata L.) larvae: a comparison with the Microtox test. Ecotox Environ Safe 59: $209-216$

Bathe R, Ullmann L, Sachsse K 1973: Determination of pesticide toxicity to fish. Schriftenr Ver Wasser-BedenLufhyg Berlin-Dahlem 37: 241-256

Djozan D, Ebrahimi B 2008: Preparation of new solid phase micro extraction fiber on the basis of atrazinemolecular imprinted polymer: Application for GC and GC/MS screening of triazine herbicides in water, rice and onion. Anal Chim Acta 616: 152-159

Doleželová P, Mácová S, Pištěková V, Svobodová Z, Bedáňová I, Voslářová E 2008: Comparison of the sensitivity of Danio rerio and Poecilia reticulata to silver nitrate in short-term tests. Interdisc Toxicol 1: 200-202

Doleželová P, Mácová S, Plhalová L, Pištěková V, Svobodová Z, Bedáňová I, Voslářová E 2009: Comparison of the sensitivity of different fish species to medical substances. Neuroendocrinol Lett 30: 153-157

Gallo D, Merendino A, Keizer J, Vittozzi L 1995: Acute toxicity of two carbamates to the guppy (Poecilia reticulata) and the zebrafish (Brachydanio rerio). Sci Total Environ 171: 131-136

Geyer HJ, Steinberg CE, Scheunert I, Bruggemann R, Schutz W, Kettrup A, Rozman K 1993: A review of the relationship between acute toxicity (LC50) of $\gamma$-hexachlorocyclohexane $(\gamma-\mathrm{HCH}$, Lindane) and total lipid content of different fish species. Toxicology 83: 169-179

Hill AJ, Teraoka H, Heidman W, Peterson RE 2005: Zebrafish as a model vertebrate for investigating chemicals toxicity. Toxicol Sci 86: 6-19

Jurčíková J, Mikula P, Dobšíková R, Némethová D, Svobodová Z 2007: Effects of metazachlor on vitellogenin induction in zebrafish (Danio rerio). Acta Vet Brno 76: 61-66

Kidd H, James DR 1991: In: The Agrochemicals Handbook third ed. Royal Society of Chemistry Information Services, Cambridge, UK. 
Kovrižnych JA, Urbančíková M 2001: Acute toxicity of selected chemicals in adult zebrafish (Danio rerio) and its early life stages - the comparative study. Biologia 56: 297-302

Mácová S, Doleželová P, Pištěková V, Svobodová Z, Bedáňová I, Voslářová E 2008: Comparison of acute toxicity of 2-phenoxyethanol and clove oil to juvenile and embryonic stages of Danio rerio. Neuroendocrinol Lett 29: 680-684

Mayer FL, Jr, Ellersieck MR 1988: Experiences with single-species tests for acute toxic effects on freshwater organisms. Ambio 17: 367-375

Mikula P, Kružíková K, Dobšíková R, Haruštiaková D, Svobodová Z 2009: Influence of propylparaben on vitellogenesis and sex ratio in juvenile zebrafish (Danio rerio). Acta Vet Brno 78: 319-326

Moretti M, Marcarelli M, Villarini M, Fatigoni C, Scassellati-Sforzolini G, Pasquini R 2002: In vitro testing for genotoxicity of the herbicide terbutryn: cytogenetic and primary DNA damage. Toxicol Vitro 16: 81-88

Muir DCG 1980: Determination of terbutryn and its degradation products in water, sediments, aquatic plants, and fish. J Agric Food Chem 28: 714-719

Office of Pesticide Programs, 2000. Environmental Effects Database (EEDB). Environmental Fate and Effects Division, US EPA, Waschington, DC.

Pištěková V, Voslářová E, Svobodová Z 2006: Porovnání akutní toxicity dusitanů pro různá vývojová stádia ryb Danio rerio. (Comparison of acute nitrite toxicity for various development stages of Danio rerio). Proceedings: Ochrana zvířat a welfare 2006. VFU Brno: 68-70 (in Czech).

Plhalová L, Mácová S, Haluzová I, Slaninová A, Doleželová P, Maršálek P, Pištěková V, Bedáňová I, Voslářová E, Svobodová Z 2009: Terbutryn toxicity to Danio rerio: Effects of subchronic exposure on fish growth. Neuroendocrinol Lett 30: 242-247

Rioboo C, Prado R, Herrero C, Cid A 2007: Population growth study of the rotifer Brachionus sp. fed with triazine-exposed microalgae. Aquat Toxicol 83: 247-253

Roberts TR, Hutson DH, Lee PW, Nicholls PH, Plimmer JR 1998: Metabolic pathways of agrochemicals. Part 1: Herbicides and plant growth regulators. 1st ed. Cambridge: The Royal Society of Chemistry, $849 \mathrm{p}$.

Stevens JT, Breckenridge CB, Simpkins J, Eldridge JC 2001: Symmetrical and asymmetrical triazine herbicides. In: Krieger R, editor. Handbook of Pesticide Toxicology. 2nd ed. San Diego, CA: Academic Press Inc. pp. 1511-1519

Svobodová Z, Vykusová B 1991: Comparing of sensitivity of Poecilia reticulata and Brachydanio rerio to contaminants. Bulletin VÚRH Vodňany 27: 12-18

Voslářová E, Pištěková V, Svobodová Z, Bedáňová I 2008: Nitrite toxicity to Danio rerio: Effects of subchronic exposure on fish growth. Acta Vet Brno 77: 455-460 